\title{
Artikkeli
}

Prologi - puheviestinnän vuosikirja 2015

\section{Esimies-alaissuhteen luottamus vuorovaikutuksessa rakentuvana ilmiönä}

\author{
Mirjami Ikonen \\ yliopistonlehtori, KTT \\ Itä-Suomen yliopisto \\ mirjami.ikonen@uef.fi
}

\section{Tiivistelmä}

Luottamus työpaikoilla on moniulotteinen tutkimuskohde, haastavuudessaan kiinnostava ja mukaansatempaava. Aihe on ajankohtainen, sillä luottamus korostuu muutoksessa ja sen viestinnässä. Luottamus työpaikoilla näkyy ilmapiirissä ja vaikuttaa työhyvinvointiin. Aiempi tutkimus on painottunut luottamuksen edellytyksiin ja seurauksiin, ei niinkään luottamuksen dynaamiseen luonteeseen. Tämän tutkimuksen tavoitteena on tutkia luottamuksen kehittymisen prosessia esimiehen ja alaisen välillä viestinnän ja vuorovaikutuksen näkökulmasta. Laadullinen tutkimusaineisto on kerätty haastattelemalla itäsuomalaisten palveluorganisaatioiden esimies-alaispareja erikseen ja yhdessä. Aineistosta paljastui, että esimiesten ja työntekijöiden välinen viestintä on altis väärinkäsityksille puolin ja toisin. Kiinnostavaa tutkimuksessa on tahattomista reagoimatta jättämisistä aiheutuneet luottamussäröt työpaikoilla. Johtamisviestinnän keinoin on mahdollista estää väärinkäsityksiä syntymästä esimerkiksi dialogin keinoin ja myös tietoisesti oikoa väärinymmärryksiä. Esimies-alaissuhteen luottamuksen rakentumisessa pienillä, arkisilla teoilla näyttää olevan suuri merkitys. Tutkimuksen mukaan luottamusta näissä suhteissa voidaan vahvistaa arvostusta ja armeliaisuutta osoittamalla. Tutkimustulokset viittaavat siihen, että kahdenvälisen luottamuksen kehittymisen ja ylläpitämisen prosessi on monimuotoisempi kuin mitä tutkimus tähän asti on osoittanut. Johtamisviestinnällä näyttää olevan keskeinen rooli luottamuksen pyörteitten momentum-kohdissa, joissa prosessin suunta joko kääntyy, pysyy ennallaan tai vahvistuu entisestään.

Asiasanat: esimies-alaissuhde, luottamuksen rakentuminen, luottamuksen rapautuminen, luottamus, momentum, vuorovaikutus 


\section{Johdanto}

Luottamus on jatkuvasti esillä puheenaiheena niin julkisissa tiedotusvälineissä kuin arkipäivän keskusteluissakin. Luottamuksesta organisaatioissa on tullut erityisesti parin viime vuosikymmenen kuluessa suosittu tutkimusaihe sekä kansainvälisesti että enenevästi Suomessakin (esim. Laine 2008; Häkkinen 2012). Luottamuksen olemukseen kuuluu, että sitä on vaikea, jopa mahdotonta yleisesti ja tyhjentävästi määritellä, vaikka jokaisella on siitä oma, kokemusperäinen käsityksensä. Yhtä yleisesti hyväksyttyä määritelmää luottamuksesta ei siis ole olemassa. Lyon, Möllering ja Saunders $(2012,1)$ kuvailevat luottamusta yhdeksi haastavimmista ja vaikeimmin ymmärrettävistä tutkimuskohteista, vaikka samanaikaisesti se on mitä kiehtovin tutkimusaihe, tarjoten loputtomasti uusia näkökulmia. Organisaatioissa luottamusta ihmisten välillä ei useinkaan edes tiedosteta, vaan pidetään itsestäänselvyytenä - kunnes luottamus alkaa säröillä. Erityisesti muutoksessa luottamuksen merkitys korostuu, kun sitä koetellaan ja testataan.

Tämä artikkelin tavoitteena on tutkia luottamuksen kehittymisen prosessia esimiehen ja alaisen välisen vuorovaikutuksen näkökulmasta. Esimiehen ja työntekijän välistä suhdetta voidaan pitää keskeisenä suhteena työpaikoilla, vaikka myös työntekijöiden keskinäiset suhteet ovat tärkeitä etenkin tiimityössä. Pääosa tutkimusaineistosta on kerätty kirjoittajan väitöstutkimusta varten ja tuloksia on osin raportoitu väitöskirjassa, jonka alkuperäisenä tarkoituksena oli kuvata ja tehdä ymmärrettäväksi luottamuksen kehittymisen prosessia ja dynamiikkaa esimies-alaissuhteissa (Ikonen 2013). Tässä artikkelissa haen vastausta tutkimuskysymykseen: Miten luottamus kehittyy esimiehen ja alaisen välisessä vuorovaikutuksessa? sekä alatutkimuskysymyksiin: Millaisissa vuorovaikutustilanteissa luottamus rakentuu? ja Millaisissa vuorovaikutustilanteissa luottamus rapautuu? Käytännön sovelluksena tutkimuksesta saadaan ymmärrystä siitä, millaisia vuorovaikutuskeinoja esimiehillä ja työntekijöillä on käytössään luottamuksen rakentamisessa, ylläpitämisessä ja mahdollisesti korjaamisessa.

\section{Luottamus esimies-alaissuhteissa}

Luottamus on monitieteinen tutkimuskohde. Sosiologiassa luottamustutkimuksella on pitkä perinne ja organisaatiotutkimuksen kentällä aihetta on tutkittu laajasti. Sen sijaan johtamisviestinnän näkökulmasta ja sosi- 
aalisesti rakentuvana ilmiönä luottamusta on tutkittu vähemmän. Tämä tutkimus asemoituu organisaatiotutkimuksen ja johtamisviestinnän kenttään. Organisaatioiden näkökulmasta yhteistyö, vuorovaikutus ja luottamus ymmärretään toisiinsa kietoutuneina ja niiden nähdään vaikuttavan organisaation tulokseen (Costa, Bijlsma-Frankema \& de Jong 2009). Aiempi organisaatiotutkimus on tunnistanut useita luottamuksen etuja: luottamus muun muassa edesauttaa yhteistyötä ja vaikuttaa työtekijöiden halukkuuteen sitoutua tekemään työnsä hyvin ja luottamus on yksi organisaation tuottavuuden avaintekijöistä (Dirks \& Ferrin 2002).

Tämän tutkimuksen kohteena on luottamuksen kehittyminen esimiesten ja alaisten välillä vuorovaikutuksessa. Aiemmasta tutkimuksesta teoreettisena lähtökohtana ovat luottamuksen kehittymisen vaihemallit (Dietz \& Den Hartog 2006; Lewicki \& Bunker 1996; Lewicki, Tomlinson \& Gillespie 2006) sekä johtajan ja alaisen vaihtosuhdeteoria eli LeaderMember Exchange (LMX) -teoria (Graen \& Uhl-Bien 1995). Lewickin ja Bunkerin (1996) mallissa luottamuksen kehittymistä kuvataan lineaarisena jatkumona laskelmointiin perustuvasta (calculus-based) luottamuksesta tietopohjaisen (knowledge-based) luottamuksen vaiheen kautta samaistumiseen perustuvaan (identification-based) luottamukseen. Luottamus nähdään vaihemalleissa staattisena, mitattavissa olevana ilmiönä ja sen nähdään vahvistuvan henkilöiden välillä ajan kuluessa. Johtajan ja alaisen vaihtosuhdeteorian mukaan toimijoiden nähdään muodostavan ainutkertainen, uniikin suhteen, johon molemmat osapuolet omalta osaltaan vaikuttavat. Tämän ainutkertaisen suhteen kehittymisessä luottamuksella on teorian mukaan keskeinen rooli. LMX-teoriassa on kyse vuorovaikutuksen ja kommunikaation lisäksi luottamuksesta, kunnioituksesta ja sitoutumisesta, jolloin luottamus nähdään prosessina esimiehen ja alaisen välillä. Sekä luottamus että johtajuus voidaan nähdä vuorovaikutteisina sosiaalisina prosesseina (Klausner 2012). Myös luottamuksen rakentamisen taito on Savolaisen (2011) mukaan esimiestaito, jota voi oppia ja jossa voi harjaantua vuorovaikutustaitoja kehittämällä.

Vaikka luottamukselle ei ole olemassa yhtä hyväksyttyä määritelmää, yksi viitatuimmista on Mayerin, Davisin ja Schoormanin (1995) määritelmä, jossa korostuu se, että luottamus syntyy ja sitä ylläpidetään vuorovaikutussuhteissa (relationaalisuus). Mayerin ym. (1995) määritelmän mukaan luottamus on haavoittuvuudelle alttiiksi heittäytymistä silloin kun ei voi kontrolloida toista osapuolta. Luottamus siis sisältää aina riskin tulla petetyksi ja mahdollisuuden haavoittua. Se on luonteeltaan vastavuoroista (Deutsch 1958), joten on luontevaa lähteä tutkimaan sen kehittymistä kahdenvälisissä suhteissa toimijoiden välisen vuorovaikutuksen näkökul- 
masta. Luhmannin (1982) mukaan mikään järjestelmä tai organisaatio ei voi pysyä koossa ilman viestintää. Tässä artikkelissa viestintä organisaatiossa nähdään Keytonin $(2011,12)$ tapaan laaja-alaisena, monimutkaisena ja loputtomana vuorovaikutusprosessina, jossa organisaation jäsenet uusintavat, ylläpitävät ja muuttavat organisaatiota. Merkitykset neuvotellaan ja rakennetaan viestinnän keinoin keskinäisessä vuorovaikutuksessa (Fairhurst \& Grant 2010). Johtajuuden määrittelen relationaaliseksi vuorovaikutukseksi, joka rakentuu vastavuoroisesti molemminpuolisessa sosiaalisessa kanssakäymisessä (Uhl-Bien 2006). Esimies-alaissuhteen käsitän tässä tutkimuksessa dialogisena suhteena perinteisen dualistisen näkemyksen sijaan. Tässä tutkimuksessa suhteet nähdään Baxterin (2004) mukaisesti dialogisina ja dialektisina eli niihin nähdään sisältyvän jännitteitä ja ristiriitaisuuksia, joita ei sinänsä nähdä konflikteina. Luottamustutkimuksessa tämä näyttäytyy esimerkiksi luottamuksen ja epäluottamuksen samanaikaisena ilmenemisenä (esim. Lewicki, McAllister \& Bies 1998).

Luottamustutkimuksessa on viime aikoina pyritty fokusoimaan tutkimuksia sen mukaan, millä tasolla luottamusta ihmisten välillä tarkastellaan: onko kyseessä ihmisten, ryhmien vai organisaatioiden välinen luottamus (Gelfand \& Fulmer 2012). Tässä tutkimuksessa fokus on kahden henkilön välisessä (dyadisessa) luottamuksessa (Yakoleva, Reilly \& Werko 2010), jolloin vuorovaikutuksen rooli luottamuksen rakentumisessa korostuu. Luottamustutkimuksella on yhä edelleen vahva kvantitatiivinen perinne (Lyon ym. 2012). Luottamusta on pyritty operationalisoimaan ja sen tasoa on pyritty mittaamaan. Tutkittaessa moniulotteista luottamuksen ilmiötä organisaatioissa sitä on jouduttu yksinkertaistamaan tutkimusasetelmiin taipuvaksi psykologiseksi tilaksi. Aiemmissa tutkimuksissa on tutkittu luottamuksen edellytyksiä ja seurauksia, mutta ei niinkään luottamuksen sosiaalista ja dynaamista luonnetta (Lewis \& Weigert 2012). Aiemmasta tutkimuksesta poiketen tässä tutkimuksessa luottamuksen ei ajatella olevan psykologinen tila eikä lineaarisesti vaiheittain kehittyvä jatkumo, vaan sosiaalisesti rakentuvaa todellisuutta.

Tässä tutkimuksessa luottamus nähdään valtavirrasta poikkeavasti vuorovaikutuksessa rakentuvana ilmiönä (Wright \& Ehnert 2010). Tarkkaan ottaen voisimme puhua luottamisen (verbi) tarkastelemisesta dynaamisena prosessina perinteisen luottamus (substantiivi) staattisena tilana sijaan. Ymmärrän luottamisen Saundersin, Skinnerin ja Lewickin (2010, 410) tavoin jatkuvana luottamisen prosessina, jossa "luottamusta luodaan narratiivina, vuorovaikutuksen ja keskustelun sosiaalisessa prosessissa" sekä Wrightin ja Ehnertin $(2010,110)$ tapaan ihmisyyteen olennaisena 
kuuluvana jatkuvana tekemisenä jossa "emme lakkaa luottamasta niin kauan kuin elämme." Luottamus on jatkuvasti liikkeessä oleva ilmiö, olemukseltaan ja luonteeltaan dynaamista luottamista (ks. myös Wright \& Ehnert 2010 ja Möllering 2013). Sosiaalisen konstruktionismin näkökulma ottaa huomioon myös sen, että kahden henkilön välisessä dyadisessa luottamuksessa (luottamisessa) myös kolmansilla osapuolilla on vaikutuksensa, tiedostamatta tai tiedostetusti (Wright \& Ehnert 2010, 109).

\section{Esimies-alaisparien haastattelut}

Tätä artikkelia koskevan tutkimuksen empiirisen aineiston pääosan olen alun perin kerännyt väitöstutkimustani (Ikonen 2013) varten kahdesta itäsuomalaisesta kolmannen sektorin palveluorganisaatiosta, joista toisessa työskentelee palkattujen työntekijöiden lisäksi myös vapaaehtoisia. Alkuperäinen haastatteluaineisto on kerätty vuosina 2009-2010. Ensimmäisestä organisaatiosta haastattelin toimialapäällikköä ja yhtä yksikönjohtajaa yhdessä, ja myöhemmin molempia erikseen. Samasta organisaatiosta haastattelin myös toista toimialapäällikköä sekä kahta tiiminjohtajaa sekä toisen tiiminjohtajan yhtä alaista. Toisessa organisaatiossa haastattelin hallituksen puheenjohtajaa ja yhtä palkatuista johtajista yhdessä sekä neljää vapaaehtoistyöntekijää. Tämän jälkeen olen hankkinut uutta aineistoa jälkimmäisestä organisaatiosta haastattelemalla yhtä palkattua johtajaa ja yhtä vapaaehtoistyöntekijää vuonna 2013.

Kyseessä on aidot esimies-alaisparit ja vuorovaikutustilanteita on tarkasteltu molempien roolien näkökulmasta. Esimies-alaisparien yhteishaastatteluja on kaksi. Aineisto antaa kuitenkin mahdollisuuden tarkastella luottamuksen kehittymisen prosessia sekä esimiehen että alaisen rooleista käsin. Johtamisen näkökulmasta vapaaehtoisten työntekijöiden ja heidän palkattujen johtajiensa haastatteluaineisto antaa mahdollisuuden tutkia luottamuksen roolia vapaaehtoistyön johtamisen kontekstissa.

Tallensin ja litteroin kaikki 14 haastattelua ja analysoin ne temaattisella sisällön analyysilla, ensin väitöstutkimustani varten ja uudelleen tätä artikkelia varten vuorovaikutuksen näkökulmasta. Analyysikysymyksinä oli muun muassa: Mistä tässä puhutaan? Mistä ei puhuta? Millainen vuorovaikutustilanne on kyseessä? Millaisia vuorovaikutuksen keinoja aineistossa ilmenee? Aineistoa uudelleen analysoidessani ryhmittelin tunnistamani erilaiset vuorovaikutustilanteet sen mukaan mitä niissä kerrottiin luottamuksen rakentumisesta tai rapautumisesta. 


\section{Luottamuksen rakentuminen}

Luottamuksen rakentumisen keskeisenä elementtinä aineistossa ilmeni kuunteleminen ja kuulluksi tulemisen kokemus. Esimies ilmaisee seuraavassa aineistonäytteessä kunnioittavansa alaistaan ja tämän osaamista kysymällä tarvittaessa neuvoa hänen vahvoilta osaamisalueiltaan:

\footnotetext{
"Tehtäväni on kuunnella ja auttaa. Nykyinen suhde on enemmänkin konsultointisuhde." (Esimiehen ja alaisen yhteishaastattelu)
}

Tämä esimies kertoo antaneensa henkilökohtaisen puhelinnumeronsa alaiselleen erityisenä luottamuksenosoituksena. Alainen osoittaa arvostavansa sitä:

"Esimiehelle voi aina soittaa ja hän kuuntelee" (yhteishaastattelu)

Kuuntelemalla aktiivisesti toista osapuolta voi osoittaa arvostusta tätä kohtaan. Molemminpuolinen arvostus ja kunnioitus näyttää rakentavan luottamusta. Vuorovaikutuksen näkökulmasta analysoituna tulkitsen tämän vuorovaikutustilanteen dialogiksi, jossa molemmat osapuolet osallistuvat ja ottavat vastuuta. Vuorovaikutus antaa mahdollisuuden löytää yhdessä uusia ratkaisuja tai ehdotuksia sen sijaan, että vuorotellen ilmaistaisiin omia näkemyksiä. Tällainen dialogisuus näyttää olevan merkityksellistä luottamuksen rakentumiselle. Aktiivinen kuuntelu ei tässä kuitenkaan viittaa ensisijaisesti pitkiin ja vaativiin keskusteluihin, vaan se näyttää voivan ilmetä myös pieninä arkisina tekoina, jotka osoittavat, että toinen osapuoli on kuullut toisen osapuolen toiveita ja odotuksia, ja pyrkii täyttämään niitä. Seuraava näyte aineistosta tuo esiin aktiivisuuden ja aloitteellisuuden merkityksen luottamuksen mahdollistamisessa esimiehen ja alaisen välillä. Tiiminjohtajana äskettäin aloittanut esimies kertoo toimintatavoistaan:

\footnotetext{
"Ja sitte ihan tämmösesti vappaamuotosesti 'Mittee kuuluu?' oon käyny siellä ovilla kyselemässä. En tiiä, voiko sitä olla liikoo.”
}

Luottamusta esimiehen ja työntekijän välillä voidaan vahvistaa monin pienin teoin. Haastateltavat kertoivat kokevansa merkityksellisinä monet arkiset vuorovaikutuksen muodoista: puhelinsoitot, sähköpostiviestit, ennalta sovitut sekä spontaanit tapaamiset. Epämuodolliset, edellisen aineistonäytteen tapaiset vapaamuotoiset kommunikoinnin tilanteet vaikuttavat merkityksellisiltä luottamuksen rakentumisessa. Lähtökohtana 
luottamus antaa rohkeutta toimia vastuullisesti ja luottamuksenarvoisesti, ja molemminpuolinen vastuunottaminen näyttää vahvistavan luottamusta. Tästä käy ilmi luottamuksen itseään vahvistava luonne - luottamus vahvistaa luottamusta:

\footnotetext{
"Uskallan, uskallan häiritä, koska mie tiiän, että jos mie en kysy tai jos mie en varmista, niin sillä saattaa olla kohtalokkaat seuraukset!”

(Vapaaehtoistyöntekijä)
}

Edellisestä sitaatista käy ilmi, miten mahdollisuus varmistaa yhteinen ymmärrys saattaa estää väärinkäsityksistä aiheutuvien luottamussäröjen synnyn. Seuraavista aineisto-otteista käy ilmi, miten esimiehen aktiivinen kuunteleminen ongelmallisissa työpaikan tilanteissa vahvistaa luottamusta. Myös vastavuoroisuus korostuu:

\footnotetext{
"Se esimiehen antama tavallaan panos siihe vuorovaikutukseen, ett onko se sit just tätä kohtaamista, läsnäolemista, asioitten jakamista ja sitten taas se ammatillinen tuki tulee sit sieltä kolleekan kautta...”

(Tiiminjohtaja)
}

Toinen toisensa arvostaminen esimies-alaissuhteessa näyttää olevan keskeinen luottamuksen rakentamisen ja ylläpitämisen elementti, sillä aineistossa molemminpuolinen arvostaminen on leimallista luottamusta rakentaville vuorovaikutustilanteille:

\footnotetext{
"Aino osaa kyllä hommansa." (Esimiehen ja alaisen yhteishaastattelu, nimi muutettu)
}

Dialogin ja arvostuksen osoittamisen lisäksi luottamus näyttää rakentuvan vuorovaikutustilanteissa, joita kuvaan armeliaisuuden (leniency) käsitteellä. Kuuntelemisen ja arvostuksen viestimisen jatkumona armeliaisuus viittaa suopeuteen, jota keskinäisessä suhteessa osoitetaan toista kohtaan luottamuksen vahvistamiseksi. Tällainen armeliaisuus saattaa myös lisätä rohkeutta ja innostaa kokeilemaan uutta. Tässä armeliaisuus on myös myötätunnon lähikäsite, sillä armeliaisuus edellyttää kykyä asettaa itsensä toisen asemaan, mutta myös kykyä tarkastella itseään ja omaa toimintaansa reflektiivisesti. Aineiston perusteella tämä tarkoittaa myös tervettä itseluottamusta, jolla näyttää olevan merkitystä myös henkilöiden väliseen luottamukseen "Ettei mollaa ja hauku itteesä, koska se tuo sitte epävarmuutta muille," kuten eräs haastatelluista vapaaehtoistyönteki- 
jöistä totesi. Arvostus ja armeliaisuus viittaavat myös luottamuksen kehkeytyvään (emergenttiin) luonteeseen. Luottamus näyttää voimistuvan tai heikkenevän erilaisten tekijöiden vaikutuksesta synnyttäen itsestään voimistuvia pyörteitä. Tässä aineistossa armeliaisuus ilmenee esimerkiksi epäitsekkyytenä, altruismina ja valmiutena asettaa toisen tarpeet omien edelle. Huomionarvioista tässä aineistossa on armeliaisuus itseään kohtaan:

\begin{abstract}
"Ja kaikki mitä olen mokannut ja muuta, niin on vaan vahvistanut sitä, että hän on ymmärtäväinen ja armollinen---Ja oon kertonu itestäni asioita jotka, jotka eivät oo...hm...eivät oo eduksi minulle. Ja silti on säilyny tää rohkaiseva ja hyväksyvä asenne." (Vapaaehtoistyöntekijä)
\end{abstract}

Kokemuksen arvostaminen voidaan tulkita luottamuksenarvoisuuden pätevyyteen ja kyvykkyyteen ulottuvuuden osoitukseksi (Meyer, ym. 1995). Tulkitsen tässä aineisto-otteesta myös armeliaisuutta itseään kohtaan, kun esimies kertoo kykenevänsä pyytämään apua tarvittaessa eikä yritäkään olla 'kaikkitietävä,' mikä vahvistaa luottamusta heidän välillään:

\footnotetext{
"Tukea on ihan sen minkä oon tarvinnu ja välillä vähän enemmänkin! Et hyvinkin helposti sitte oon kääntyny... Elinahan on, hällä on niin kamalan pitkä kokemus ja ollu jo aikasemmin, et se on helppokin sit kääntyy ja kyssyy sitä neuvoo. Ja vaikkei neuvoa kysyiskää, niin kyssyy sitten tai pohdiskella tai miettii, et oonko mie nyt ihan täysillä ajattelemassa vai ihan hunningolla (naurua)... Et aina sitä suuntaa, suuntaa vähä niiku. $\mathrm{Ku}$ kuitenkaan kaikille ei voi puhua, et sehän se siinä on.” (Yksikönjohtaja esimiehestään, nimi muutettu)
}

Armeliaisuus näyttää hälventävän ja murentavan pelkoja. Tässäkin aineistossa pelot näyttävät kumpuavan ja vahvistuvan erityisesti puhumattomuudesta ja vaikenemisesta, mikä tuli selkeämmin esiin väitöstutkimukseni toisesta, narratiivisesta aineistosta (Ikonen 2013). Viestinnän puute työyhteisöissä näyttää altistavan väärinkäsityksille. Armeliaisuudesta toista osapuolta ja itseään kohtaan ei johtamisviestinnän näkökulmasta ole juurikaan keskusteltu. Armeliaisuus voidaan ymmärtää sallivuutena, nimenomaan silloin kun sallitaan erehtyvyys ja virheet - sekä itselle että toiselle. Erehdyksiä ei peitellä vaan ne otetaan rohkeasti esille ja nähdään mahdollisuuksina oppia esimerkiksi dialogin keinoin. Näissä tilanteissa luottamukselle annetaan mahdollisuus vahvistua, kun epäilykselle ei jää sijaa. Tämän aineiston perusteella armeliaisuus näyttää hälventävän pel- 
koa silloin, kun ymmärretään, että virheitä ei tarvitse pelätä. Kuten edellä mainittu kokenut esimies Elina tutkimusaineistossa toteaa, "johtajan pitää olla vähän hupelo." Tällä hän kuvasi sitä, miten hänen mielestään johtajan tulee heittäytyä esimerkiksi yhteisissä illanvietoissa hieman naurunalaiseksi. Tällä tavoin käyttäytymällä hän ei suinkaan menetä auktoriteettiaan vaan tämän haastateltavan mukaan luottamus alaisten ja esimiehen välillä vahvistuu tällaisen "hupeloksi" heittäytymisen myötä.

Armeliaisuus kuvaa yläkäsiteenä luottamusta rakentavia vuorovaikutustilanteita. Tässä aineistossa luottamus rakentui ikään kuin armeliasuuden hengessä, millä tarkoitan sitä, että toimija on armelias itselleen ja omille erehdyksilleen, mutta ymmärtää myös toisen osapuolen toisinaan tahattomasti tekevän virheitä, esimerkiksi saattaa jättää reagoimatta toisen osapuolen yhteydenottoon tai on vuorovaikutustilanteessa passiivinen tai jopa välinpitämätön. Tässä tutkimuksessa luottamus ymmärretään sosiaalisesti rakentuvana ilmiönä, joten analyysi perustuu toimijoiden käsityksiin itsestään ja toiminnastaan niissä tilanteissa, joista he haastatteluissa kertoivat.

\section{Luottamuksen rapautuminen}

Aineiston analysointi tuotti joitakin kuvauksia myös vuorovaikutustilanteista, joissa luottamus rapautuu. Keskeistä näissä tilanteissa on reagoimattomuus ja passiivisuus, jossa vuorovaikutus kielletään kokonaan tai siihen ei antauduta. Tässä aineistossa reagoimattomuus johti helposti itseään voimistavaan kierteeseen. Tyypillisimmillään reagoimattomuus ilmenee tahattomana passiivisuutena, esimerkiksi kun esimies ei ollut ehtinyt muilta tehtäviltään reagoida ja näin ollen luottamus oli jo ehtinyt saada särön:

\footnotetext{
"Jos asia on sovittu, mutta sitä ei tehdäkään niin kuin on sovittu, niin ne on tietysti semmoisia pettymyksiä. Monesti ihmisille on tullut sellaisia yllättäviä asioita, jotka on sitten kuormittanu, että ei ookaan sitten pystyny tai jaksanu. Jos asia ei tuu hoidetuks, niin peiliin pittää katsoo. Onko vuorovaikutusta ollut tarpeeksi, onko ymmärretty samalla tavalla. Oliko vuorovaikutusta ollu riittävästi - siihen se kaikki aina kulminoituu.” (Tiiminjohtaja)
}

Passiivisuus ja välinpitämättömyys näyttäytyivät ikään kuin kuulluksi tulemisen kokemuksen kääntöpuolena (Ikonen 2013). Aineistosta käy ilmi, että jopa tahattomat reagoimatta jättämiset aiheuttavat pettymystä ja luottamuksen murenemista esimiesten ja työntekijöiden välillä. Samas- 
ta passiivisuuden ilmiöstä vuorovaikutuksessa on kirjoittanut hiljattain myös esimerkiksi Aira (2012). Tulkintani mukaan reagoimattomuudessa ei välttämättä ole kyse välinpitämättömyydestä tai laizzes faire -johtamistyylistä, vaan se näyttää ilmenevän tahattomana. Toisaalta avoimen yhteistyön ja luottamuksen rakentamisen esteenä voivat toimia kulttuuriset rakenteet kuten syvään juurtuneet uskomukset, tavat ja viestinnän esteet (Savolainen, Lopez-Fresnó \& Ikonen 2014), kuten seuraavasta käy ilmi:

”Ja sit mä tein oman päätöksen, että ei ennää sitten niitä [suunnitelmien näyttäminen esimiehelle], ellei itellä oo semmonen epävarma olo---välillä ehkä toivoiskii, että ois joku sillee, tiiätkö, sillee ku on yhessä suunniteltu, niin se on ollu hirveen antosaa, et siinä on saanu tukee ja aatellu, että me ollan tää nyt yhessä pohdittu. Ehkä se pitäis vaan olla ite rohkee kysymään, et välillä ei viiti sit häiritä häntä, ett mä tiiän, ett hänellä on paljo töitä ja yksikin vaiva täältä...” (Vapaaehtoistyöntekijä)

Tässä tutkimuksessa pelot juonsivat juurensa epävarmuudesta ja väärinymmärryksistä ja pettymyksen tunteet näyttivät usein voimistavan niitä (ks. myös Ikonen 2013). Aiemmat luottamuksen rikkoutumisen kokemukset saattoivat olla pelkojen taustalla ruokkimassa itseään vahvistavaa kierrettä. Pelot näyttävät olevan tyypillinen itseään vahvistavan pyörteen osa-alue (Costa, ym. 2009). Tulkitsen väitöstutkimuksessani (Ikonen 2013), että epäluottamuksen noidankehän voimakkaimpia pyörteitä aiheuttavat pelot, joita toistuvat ignoroinnit ja väärinkäsitykset ruokkivat. Tässä tutkimuksessa pelkoon pohjautuviksi kuvattujen vuorovaikutustilanteiden eräänlaiseksi vastinpariksi olen nimennyt armeliaisuuden sillä se hälventää pelkoja, kun erehtyminen sallitaan ja väärinkäsityksiä pyritään aktiivisesti selvittämään ja käsittelemään siten, että luottamus voi rakentua uudelleen. Luottamisen prosessi voi jatkua positiivisena pyörteenä:

\footnotetext{
"Ett jotku asiat aattelloo, ett tää on iha itestääselevä, mut se ei ookkaan. Nii sitte pittää aina mennä peilin etteen ja kahtoo, että nytpä oon tämän asian epäselevästi sanonu tai en riittävän monesti ja huolehii, ett kaikilla on se tieto. Ku meilläkii ihmiset liikkuu paljo ja tekkee liikkuvaista työtä, niin ne on niitä kipupisteitä varmaan sitte semmossii." (Tiiminjohtaja)
}

Luottamuksen rakentumisen näkökulmasta tämä on keskeistä, sillä tulkitsen armeliaisuuden nimenomaan väärinymmärrysten ja pelkojen vastinpariksi. Tulkitsen aineistosta, että armeliaisuus vuorovaikutuksessa tarkoittaa sitä, että huomioidaan oma ja toisen erehtymisen mahdollisuus 
ja ymmärretään väärinymmärryksen mahdollisuus; annetaan anteeksi väärinymmärryksistä aiheutuvat luottamusrikot ja ollaan valmiit rakentamaan luottamusta uudelleen. Aineisto antaa myös viitteitä siitä, että joissakin tilanteissa tunteiden ilmaisun ja niistä puhumisen salliminen vahvistaa luottamusta.

\section{Luottamuksen momentumit ja pyörteet}

Raportoin tulosten yhteenvedon metaforista ilmaisutapaa käyttäen (Eriksson \& Kovalainen 2008; Fleming 2005; Knudsen 2003) ja kuvaan luottamusprosessin dynamiikkaa pyörteinä. Tämän pyörteen (vortex) käsitteen olen lainannut fysiikan alalta vesi- ja aerodynamiikasta. Pyörre kuvaa elävästi luottamuksen luonnetta esimies-alaissuhteissa. Käytän luottamuksen pyörteitä vertauskuvana luottamuksen dynamiikasta ja viittaan sillä ilmiötä kuvaaviin spiraalimaisiin luottamusprosessin muotoihin. Jo Zand (1972) on viitannut luottamuksen prosessiin, jossa luottamus dynaamisesti vahvistuu spiraalimaisesti. Tässä aineistossa luottamuksen kehittymisprosessissa ilmenevät pyörteet voidaan kuvata spiraalimaisina, itsestään voimistuvina kehinä.

Tulokset viittaavat siihen, että luottamuksen kehittymisessä vuorovaikutuksessa ilmenee erityisiä episodeja 'momentumeja', jolloin kahdenvälinen luottamus saattaa pyrähtäen vahvistua tai jopa kääntyä luottamuksen rakentumiseksi tai yhtäkkiä luottamus saattoi rapautua. Viestinnän näkökulmasta keskeistä näyttää olevan väitöstutkimukseni esiin tuomat luottamuksen momentumit. Ne eivät ole ainoastaan luottamuksen käännekohtia vaan myös niitä hetkiä tai episodeja, joissa luottamus vahvistuu tai vastaavasti kytevä epäluuloisuus tai mureneva luottamus alkaa rapautua epäluottamukseksi.

Tutkimuksessa löytyi luottamuksen pyörteitä molempiin suuntiin: sekä heikkenemisen pyörre että vahvistumisen pyörre. Se, että luottamus heikkenee ja jopa romahtaa hetkessä, on arkikokemuksenkin perusteella tuttua. Tämän tutkimuksen perustella myös luottamuksen nopea 'pyrähdysmäinen' vahvistuminen vuorovaikutuksen keinoin on ilmeistä. 


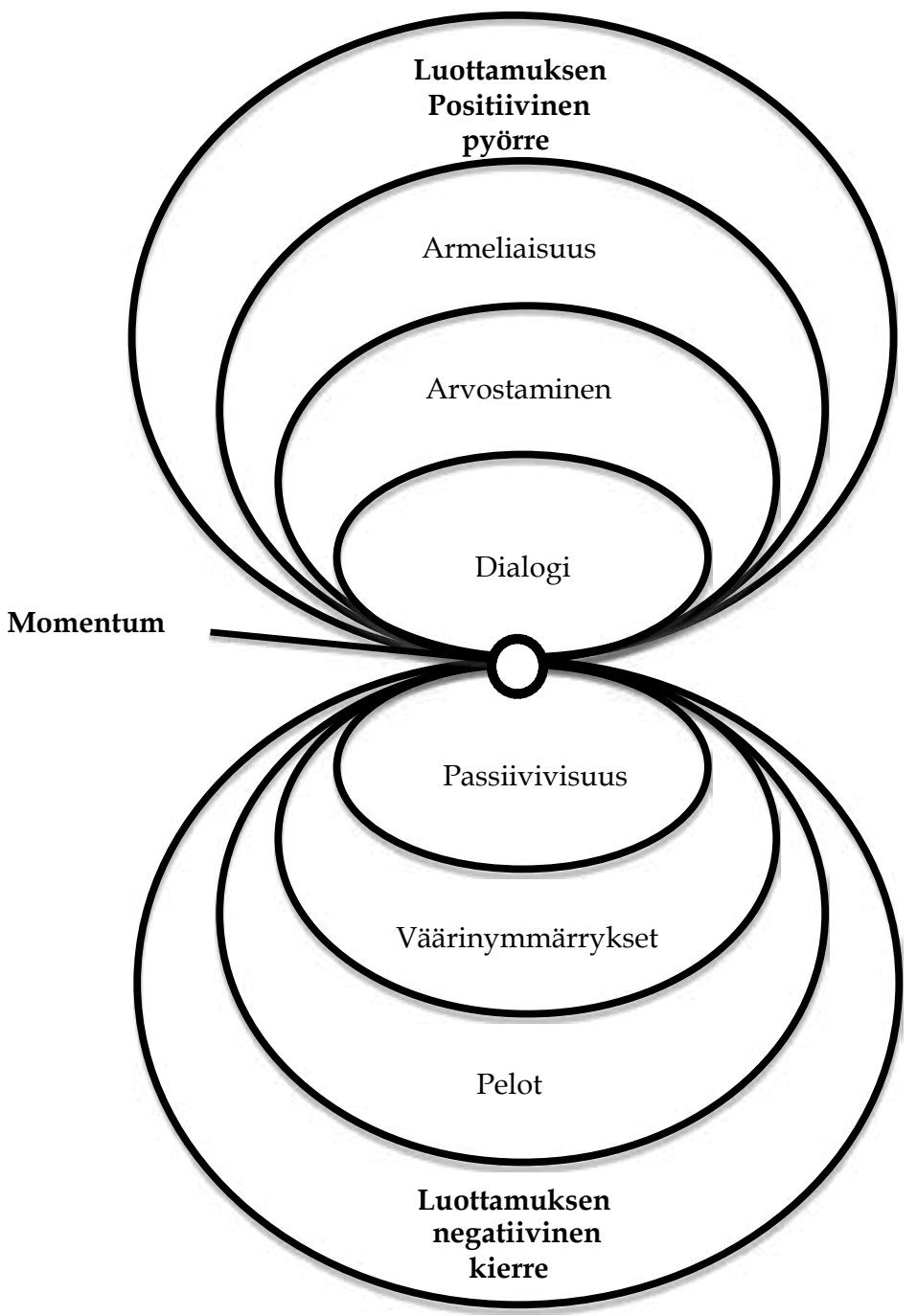

KUVIO 1 Tutkimustulokset luottamuksen pyörteinä Ikosta (2013) mukaillen

Luottamus esimiesalaissuhteessa näyttäytyy jatkuvasti muotoutuvana ja kehkeytyvänä prosessina, jonka vahvistamista kuvaan arvostuksen ja armeliaisuuden käsitteillä. Luottamus näyttää kehittyvän pyörteisesti, momentumeissa voimistuen ja vahvistuen tai pysyen ennallaan (ikään kuin 
samalla kehällä) tai luottamussärön tai -rikon johdosta kääntyen epäluottamuksen pyörteeksi. Vaikuttaa siltä, että eri osapuolet voivat kokea rikot eri tavoin, jopa niin, että toinen osapuoli on tietämätön aiheuttamastaan säröstä.

Tämän tutkimuksen tulosten mukaan luottamus on vahvasti vuorovaikutuksellinen ilmiö, jonka dynamiikassa keskeistä on molemminpuolinen viestintä. Luottamus, erityisesti luottaminen (verbinä) on tässä aineistossa johtajuuden ydintä. Tässä tutkimuksessa aloitteellisuus ja aktiivisuus korostuvat keskeisenä luottamuksen rakentamisen ja vahvistamisen keinona. Aiempaan luottamustutkimukseen nähden voidaan ajatella, että dialogin käyminen vahvistaa Lewickyn ja Bunkerin (1996) mallin tietoon pohjautuvaa luottamusta, mutta toisaalta dialogia tarvitaan myös samaistumiseen perustuvan luottamuksen ylläpitämisessä. Toisaalta voidaan pohtia, että armeliaisuus voisiko vahvistaa laskelmointiin perustuvaa luottamusta nopeastikin? Lewickyn ja Bunkerin em. mallissa luottamusta kuvataan lineaarisesti kehittyvänä jatkumona, mutta tämän tutkimuksen pohjalta voidaan kysyä, voisiko eri vaiheiden väliltä löytyä samankaltaisia momentumeja kuin tässä tutkimuksessa. Tutkimustuloksia voidaan peilata aiempaan luottamustutkimukseen ja hakea yhtymäkohtia luottamuksenarvoisuuden ulottuvuuksiin eli ABI-malliin (Ability, benevolence, integrity; Mayer, ym. 1995). Dialogi ja siihen antautuminen voidaan ajatella esimerkkinä integriteetistä, arvostus on kytköksissä pätevyyteen ja kyvykkyyteen ja armeliaisuus osa hyväntahtoisuutta (benevolence). Vaikuttaa siltä, että hyväntahtoisuuden käsite luottamuksenarvoisuuden ulottuvuutena on moniulotteisempi ja vivahteikkaampi kuin aiempi tutkimus on osoittanut.

\section{Johtopäätökset ja pohdinta}

Tämän tutkimuksen aineisto on peräisin kahdesta kolmannen sektorin organisaatioista. Yhteishaastatteluja oli kaksi. On ilmeistä, että yhteishaastatteluissa ei tuoda esille kaikkia niitä näkökohtia kuin yhden henkilön haastatteluissa. Yksilöhaastatteluissa haastateltavat puhuivat vapaammin kuin yhteishaastatteluissa ja heidän puheenvuoronsa olivat pitempiä. Yhteishaastattelut olivat luonteeltaan keskustelunomaisia: puheenvuorot olivat lyhempiä kuin yksilöhaastatteluissa haastateltavien keskustellessa keskenään. He jatkoivat siitä mihin toinen lopetti eikä tutkijan tarvinnut juurikaan ohjailla keskustelua. Sen sijaan yksilöhaastatteluissa haastateltavat puhuivat tutkijalle ja kuvailivat tilanteita seikkaperäisesti. Yhteishaastatteluissa ei juurikaan puhuttu luottamuksen rikkoutumisesta, sillä tutkija 
oli niitä tehdessään keskittynyt luottamuksen rakentumiseen. Aineisto ei anna mahdollisuutta kovin pitkälle meneviin johtopäätöksiin luottamuksen rapautumisesta, vaan tässä olen nojannut väitöstutkimuksen toiseen aineiston tuottamiin tuloksiin (Ikonen 2013). Tutkimuksen rajoituksena on luottamuksen kontekstuaalisuus ja tilanneriippuvuus. Jatkossa olisi kiinnostavaa tutkia myös luottamuksen palauttamista luottamussäröjen ja rikkojen jälkeen, mihin tämä aineisto ei anna juurikaan mahdollisuuksia.

Vaikuttaa siltä, että tulevaisuuden organisaatioissa vuorovaikutustaitojen merkitys tulee entisestään korostumaan. Teknologiavälitteinen viestintä toisaalta haastaa luottamuksen perinteisen rakentamisen vuorovaikutuksessa kasvokkain, mutta samalla myös mahdollistaa uusia vahvistamisen muotoja. Asioita voidaan kommunikoida, tarvittaessa tarkistaa ja varmistaa eri viestintävälineitä käyttäen. Luottamuksen rakentumisessa tärkeiksi koetut pienet rohkaisevat ja tukea osoittavat viestit on entistä helpompaa lähettää. Tutkimustuloksissa korostui ylipäätään vuorovaikutuksen merkitys luottamuksen perustana ja vuorovaikutustaidot johtamistaitoina.

Tulokset implikoivat käytännön johtamistyöhön erityisesti tietoisuuden lisäämistä luottamuksen kehittymisestä, sillä osapuolet saattavat tarkoittamattaankin murentaa luottamusta passiivisella tai välinpitämättömällä käyttäytymisellään ja viestinnällään. Pahimmillaan voidaan puhua jopa epäluottamuksen noidankehästä. Luottamuksen rakentaminen vuorovaikutustaidoin voidaan nähdä paitsi esimiestaitona myös työyhteisötaitona, jolla on merkittävä rooli työhyvinvoinnin edistäjänä (ks. myös Savolainen 2011). Suomalainen muuttuva työelämä voisi parhaimmillaan johtaa siihen, että perinteinen 'vaikenemisen kulttuuri' tulee haastetuksi. Esimerkiksi Y-sukupolven taipumus vaatia välitöntä palautetta voisi olla yksi avaintekijä kohti entistä dialogisempaa työpaikkakulttuuria.

Tutkimustulokset viittaavat siihen, että kahdenvälisen luottamuksen kehittymisen ja ylläpitämisen prosessi on dynamiikaltaan monimuotoisempi kuin mitä aiempi tutkimus on osoittanut. Luottamusprosessi esimiesten ja työntekijöiden välillä näyttäytyi spiraalimaisina, itsestään voimistuvina pyörteinä. Toisaalta tutkimukseni osoittaa, että luottamusta voidaan vahvistaa pienillä, arkisilla teoilla, etenkin silloin, kun sekä esimies että alainen kykenevät arvostamaan toisiaan.

Tutkimuksessa ilmeni esimerkkejä organisaation toimijoiden keinoista ylläpitää ja vahvistaa luottamusta sekä toisaalta estää sitä rapautumasta. Aloitteellisuutta luottamuksen rakentamisessa voidaan pitää ensisijaisesti esimiehen tehtävänä. Tutkimustulosten perusteella arvostuksen ja armeliaisuuden osoittaminen työpaikoilla näyttää olevan keskeistä. Tutkimus 
antaa viitteitä siitä, että arvostuksen osoittamisella ja armeliaisuudella eri vivahteineen saattaisi olla suuri merkitys myös luottamuksen palauttamisen prosessissa.

Luottamuksen dynamiikan ymmärtäminen on keskeistä johtamisviestinnässä ja esimiestyössä. Esimiesten ja työntekijöiden välinen viestintä nykypäivän organisaatioissa näyttäisi olevan altis väärinkäsityksille, arvatenkin työelämän hektisyyden ja kiireisyyden takia, erityisesti erilaisissa asiantuntijatehtävissä ja tietointensiivisissä organisaatioissa itsenäisen työotteen myötä. Väärinymmärrykset saattavat alkaa pienistä asioista, mutta tässä aineistossa niillä näyttää olevan itseään vahvistava voima. Näyttää siltä, että hyvään tarvitaan ponnistelua kun taas pahaan on vaivatonta luisua itsestään, kuten muun muassa Baumeister ym. (2001) ovat tuoneet esille.

\section{Kirjallisuus}

Aira, A. 2012. Toimiva yhteistyö - työelämän vuorovaikutussuhteet, tiimit ja verkostot. Väitöskirja, Jyväskylän yliopisto.

Baumeister, R. F., Bratslavsky, E., Finkenauer, C. \& Vohls, K. D. 2001. Bad is stronger than good. Review of General Psychology, 5(4), 323-370.

Baxter, L. 2004. Relationships as dialogues. Personal Relationships 11, $1-22$.

Costa, A. C., Bijlsma-Frankema, K. \& de Jong, B. 2009. The role of social capital on trust development and dynamics: implications for cooperation, monitoring and team performance. Social Science Information, 48(2), 199-228.

Deutsch, M. 1958. Trust and suspicion. Journal of Conflict Resolution 2, 265-279.

Dietz, G. \& Den Hartog, D. N. 2006. Measuring trust inside organisations. Personnel Review, 35 (5), 557-588.

Dirks, K. T. \& Ferrin, D. 2002. Trust in leadership: Meta-analytic findings and implications for research and practice. Journal of Applied Psychology, 87, 611-628.

Eriksson, P. \& Kovalainen, A. 2008. Qualitative Methods in Business Research. London, SAGE.

Fairhurst, G. T. \& Grant, D. 2010. The Social Construction of Leadership: A Sailing Guide. Management Communication Quarterly 24(2), 171210. 
Fleming, P. 2005. Metaphors of resistance. Management Communication Quarterly 19, 45-66.

Fulmer, C. A. \& Gelfand, M. J. 2012. At what level (and in whom) we trust: Trust across multiple organizational levels. Journal of Management, 38 (4), 1167-1230.

Hosking, D. M. 2007. Not leaders, not followers. A postmodern discourse of leadership processes. In: B. Shamir, R. Pillai, M. C. Bligh \& M. Uhl-Bien (eds.), Follower-centered Perspectives on Leadership. A Tribute to the Memory of James R. Meindl. Greenwich, CT: Information Age Publishing, pp. 243-263.

Häkkinen, S. 2012. Towards a trust-based model of leadership within the leader-member exchange theory framework: a qualitative study of leaders' trustworthiness in the SME context. Dissertations in Social Sciences and Business Studies no 45. Publications of the University of Eastern Finland.

Ikonen, M. 2013. Trust Development and Dynamics at Dyadic Level. A Narrative Approach to Studying Interpersonal Trust in Leader-Follower Relationships. Dissertations in Social Sciences and Business Studies no 53, Publications of the University of Eastern Finland.

Jones, G. R. \& George, J. M. 1998. The Experience and Evolution of Trust: Implications for Cooperation and Teamwork. Academy of Management Review, 23(3), 531-546.

Klaussner, S. 2012. Trust and leadership: Toward an Interactive Perspective. Journal of Change Management, 12 Nov, 1-2.

Knudsen, S. 2003. Scientific metaphors going public. Journal of Pragmatics, 35, 1247-1263

Laine, N. 2008. Trust in Superior-Subordinate Relationships. An empirical study in the context of learning. Tampere: University of Tampere.

Lewikci, R. J. \& Bunker, B. B. 1996. Developing and Maintaining Trust in Work Relationships. Reprinted in: Z. A. Bachman R. (toim.), Landmark papers on Trust, Vol II. Cheltenham UK: Edward Elgar Publishing, 388413.

Lewicki, R. J., McAllister, D. J. \& Bies, R. J. 1998. Trust and distrust: new relationships and realities. Academy of Management Review, 23(3), 438458.

Lewicki, R. J., Tomlinson, E. C. \& Gillespie, N. 2006. Models of Interpersonal Trust Development: Theoretical Approaches, Empirical Evidence, and Future Directions. Journal of Management, 32(6), 9911022. 
Lewis, J. D. \& Weigert, A. J. 2012. The Social Dynamics of Trust:

Theoretical and Empirical Research, 1985-2012. Social Forces 91(1), 25-31.

Luhmann, N. 1982. Systems Theory, Evolution Theory, and Communication Theory, in: The Differentiation of Society, translated by Stephen Holmes and Charles Larmore. New York: Columbia University Press, 255-27.

Lyon, F., Möllering, G. \& Saunders, M. N. 2012. Introduction: the variety of methods for the multi-faceted phenomenon of trust. In: F. Lyon, G. Möllering \& M. N. Saunders (eds.), Handbook of Research Methods on Trust. Cheltenham, UK: Edward Elgar, 1-15.

Mayer, R., Davis, J. \& Schoorman, D. 1995. An integrative model of organizational trust. Academy of Management Review, 20(3), 709-734.

Möllering, G. 2006. Trust: Reason, Routine, Reflexivity. Oxford: Elsevier.

Möllering, G. 2013. Process views of trusting and crises. Teoksessa R. Bachmann \& A. Zaheer (toim.), Handbook of Advances in Trust Research. Cheltenham: Edward Elgar, 285-305.

Savolainen, T. 2011. Luottamusjohtajuus inhimillisen pääoman uudistamisessa. Teoksessa A. Puusa \& H. Reijonen (toim.), Aineeton pääoma organisaation voimavarana. UNIpress, 117-141.

Savolainen, T., López-Fresno, P. \& Ikonen, M. 2014. TrustCommunication Dyad in Inter-Personal Workplace Relationships Dynamics of Trust Deterioration and Breach. Electronic Journal of Knowledge Management 12(4), 232-240.

Uhl-Bien, M. 2006. Relational Leadership Theory: Exploring the social processes of leadership and organizing. The Leadership Quarterly, 17(6), 654-676.

Wright, A. \& Ehnert, I. 2010. Making sense of trust across cultural contexts. In: M. N. K. Saunders, D. Skinner, G. Dietz, N. Gillespie \& R. J. Lewicki (eds.), Organizational Trust. A Cultural Perspective. Cambridge: Cambridge University Press, 107-126.

Yakoleva, M., Reilly, R. R. \& Werko, R. 2010. Why Do We Trust? Moving Beyond Individual to Dyadic Perceptions. Journal of Applied Psychology, 95(1), 79-91.

Zand, D. 1972. Trust and managerial problem solving. Reprinted in: R. Bachmann \& A. Zaheer (eds.), Landmark Papers on Trust Vol. I. Cheltenham, UK: Edward Elgar, 3-47. 